\title{
Case study of the diet and parasite fauna of and extremely rare fish species Lumpenus lampraeteformis (Perciformes, Stichaeidae) from the Gulf of Gdańsk (south Baltic Proper)
}

\author{
Beata Więcaszek, Ewa Sobecka, Marek Szulc, Klaudia Górecka
}

Received - 08 September 2017/Accepted - 19 November 2017. Published online: 31 March 2018; Inland Fisheries Institute in Olsztyn, Poland Citation: Więcaszek B., Sobecka E., Szulc M., Górecka K. 2018 - Case study of the diet and parasite fauna of and extremely rare fish species Lumpenus lampraeteformis (Perciformes, Stichaeidae) from the Gulf of Gdańsk (south Baltic Proper) - Fish. Aquat. Life 26: 75-79.

\begin{abstract}
The snakeblenny, Lumpenus lampretaeformis, is a post glacial relict from the last ice age in the Baltic Sea. Reliable data on its diet, parasite fauna, distribution, population size, and population trends in the Baltic Sea are lacking. In the Polish zone it has been observed only in ICES subdivisions 25 (Slupsk Furrow) and 26 (Puck Bay, Krynica Morska, Władysławowo and Vistula mouth fishing grounds) at depths of 30-70 m; however, in recent decades only one finding of snakeblenny in Polish waters has been reported. This paper reports the record of one female specimen from the Gulf of Gdańsk. The individual's morphological characters, stomach contents, parasitic fauna, age and gonadosomatic index were examined. The parasitological examination, which was undertaken for the first time on a specimen from the Baltic Sea since the 1930s, revealed that L. lampretaeformis was the host of one parasite species, namely a juvenile acanthocephalan Echinorhynchus gadi. Additionally, Pontoporeia fermorata and Halicryptus spinulosus were recorded in the stomach of snakeblenny for the first time in the Baltic Sea.
\end{abstract}

\footnotetext{
B. Więcaszek [झ], E. Sobecka, K. Górecka

Department of Hydrobiology, Ichthyology and Biotechnology

of Breeding, Faculty of Food Sciences and Fisheries

West Pomeranian University of Technology in Szczecin

71-550 Szczecin, 4, K. Królewicza st., Poland

e-mail: beata.wiecaszek@zut.edu.pl

M. Szulc

Department of Sea Fisheries, Maritime University

Wały Chrobrego 1/2, 70-500 Szczecin, Poland
}

Keywords: Lumpenus lampretaeformis, Pontoporeia fermorata, Halicryptus spinulosus, Echionorhynchus gadi, Gulf of Gdańsk

Data concerning fish species that are caught occasionally or are not commercially significant in the Polish zone of Baltic Sea are available sporadically, because monitoring is performed only for several commercial fish species including herring, Clupea harengus (L.), Atlantic cod, Gadus morhua L., and flounder, Platichthys flesus (L.) (Psuty-Lipska and Garbacik-Wesołowska 1998, Dudko 2008, Dudko et al. 2015). The appearance of rare non-commercial or visiting fish species in Polish research catches in the east Baltic Proper in 1976-2004 was reported by Grygiel and Trella (2007).

Lumpenus lampretaeformis (Walbaum) is distributed in the North Atlantic. The isolated population in the Baltic Sea is a post glacial relict from the last ice age, and it probably reached the Baltic Sea during the early saltwater stage of the sea. It occurs on soft bottoms from the Kattegat to the Gulf of Bothnia and is mainly distributed at depths between 30 and $120 \mathrm{~m}$ (Muus and Nielsen 1999). In their monitoring surveys in the Polish zone, Grygiel and Trella (2007) reported the sporadic occurrence of this species in 1981-1994 in ICES subdivisions 25 
(Słupsk Furrow) and 26 (Puck Bay, Krynica Morska, Władysławowo, and Vistula mouth fishing grounds) at depths of 30-70 m; however in recent decades only one finding of snakeblenny from Polish waters (Puck Bay) has been reported (Pieckiel and Wawrzyniak 2016). Skóra (1996) lists 71 species as currently or previously occurring permanently or temporarily in the waters of the Gulf of Gdańsk (ICES SD 26) (70\% of them are local fishes), and one of them is L. lampretaeformis. However, reliable data on its distribution, population size, population trends, diet, and parasite fauna in the Baltic Sea are lacking. In the Baltic Sea the species is of no direct economic importance, and it is hard to catch using standard commercial trawls because of its elongated, almost eel-like body and its small size. It also occurs rarely and at great depths with a tendency to burrow in the mud, and these are probably among the reasons why L. lampretaeformis has not been thoroughly studied in Baltic Sea to date. The parasitological examination undertaken in this paper is the first to be done on a specimen from the Baltic Sea since Markowski (1933). Moreover, to date, no examinations of the diet or gonadosomatic index of snakeblenny have been performed on specimens from the Polish zone of the Baltic Sea.

The aim of the study was to present the unique record of L. lampretaeformis in the Gulf of Gdańsk (southern Baltic) and to supplement knowledge of its diet, age, parasite fauna, and gonadosomatic index.

The individual collected was measured and weighed and basic metric and meristic measurements of taxonomical significance were taken and used to identify the specimen to the level of the species. According to Makushok (1986), the following characters are of taxonomical significance: dorsal fin spine and pelvic and anal finray counts; the presence or absence of palatine teeth and scales on the cheek; the shape of the caudal fin; body depth. These characters were measured using ToupViev 3.7 image analysis software. Additionally, the stomach contents, age (estimated by otolith reading), and the sex of the specimen examined were determined using macroscopic and microscopic methods. The specimen's maturity stage was estimated using Maier's scale (Williams 2007). The gonadosomatic index was calculated with the formula: GSI $=\mathrm{Wg} \times \mathrm{W}^{-1}$ $\times 100 \%$, where $\mathrm{Wg}$ - weight of the gonads, $\mathrm{W}$ - wet weight of the fish.

The stomach contents were identified using Nikon SMZ 1000 and Motic Series K stereoscopic microscopes. The species of prey items were identified using references keys and species descriptions in the works by Żmudziński (1990) and Hayward and Ryland (2011). The parasitological examination focused on the skin, vitreous humor, eye lens, mouth and nasal cavities, gills, gonads, gastrointestinal tract, kidneys, swim bladder, urinary bladder, gall bladder, peritoneum, and muscles. The parasites found were prepared for species determinations (Popiołek 2016) by viewing specimens in fresh preparations on glass slides or after immersion in glycerin under transient light using an Olympus BX 50 microscope fitted with an AxioCamERc5S digital camera.

One specimen of snakeblenny, L. lampretaeformis, was collected on April 8, 2015 as bycatch in a commercial fish species monitoring survey conducted from a research vessel in the Gulf of Gdańsk with a standardized bottom trawl used in accordance with ICES recommendations (International Baltic Fish Survey Trawl, 20 $\mathrm{mm}$ mesh size in the codend), at a depth of $40.9 \mathrm{~m}$ (54 $\left.32^{\circ}-54^{\circ} 31^{\prime} \mathrm{N}, 18^{\circ} 45^{\prime}-18^{\circ} 46^{\prime} \mathrm{E}\right)$ (Fig. 1). The specimen appeared to be a female aged $6+$, measuring 26.3 $\mathrm{cm}$ total length (TL) and $23.6 \mathrm{~cm}$ body length (SL). The weight of the specimen was $25.0 \mathrm{~g}$. The shape of otoliths (sagitta) and the age determined are presented in Fig. 2.

Lumpenus lampretaeformis had a very elongated body, with a maximum body depth that was $6.57 \%$ of its standard length SL. The head length constituted $11.86 \%$ of SL, while head depth was $3.89 \%$ of SL. The horizontal eye diameter was $10.71 \%$ of head length. Palatine teeth were absent. The dorsal fin was long, with 69 spines, and it was well separated from the caudal fin with 16 fin rays that were long and pointed. The anal fin had 48 fin rays with five spines and 43 soft fin rays. The pelvic fins with one spine and three soft rays each were situated anteriorly to 


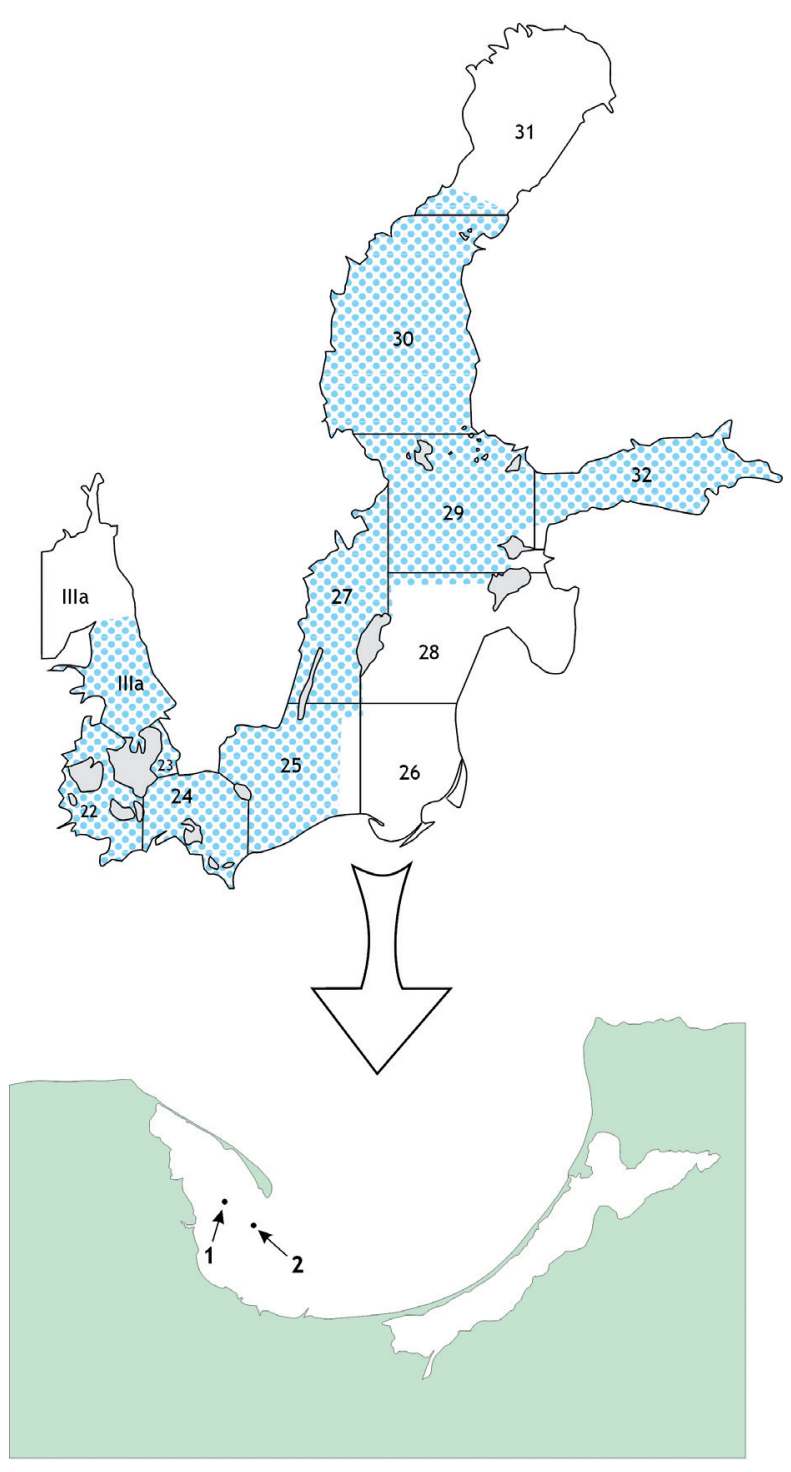

Figure 1. Distribution of Lumpenus lampretaeformis in the Baltic Sea (HELCOM area) with the locations of two findings. 1 - in the Puck Bay (Pieckiel and Wawrzyniak 2016), 2 - current study. Map available at (http://www.helcom.fi/Red\%20List\%20Species\%20Information\%20Sheet/HELCOM\%20Red\%20List\%20L umpenus\%20lampretaeformis.pdf); modified for the present study.

the pectoral fins. The entire cheek was covered with scales.

Ten specimens of Pontoporeia fermorata Krøyer, 1842 (Malacostraca, Amphipoda, Gammaridea, Pontoporeiidae) and one specimen of Halicryptus spinulosus von Siebold, 1849 (Cephalorhyncha, Priapulida, Priapulidae) were noted in the stomach of L. lampretaeformis as food items. Four parasites were

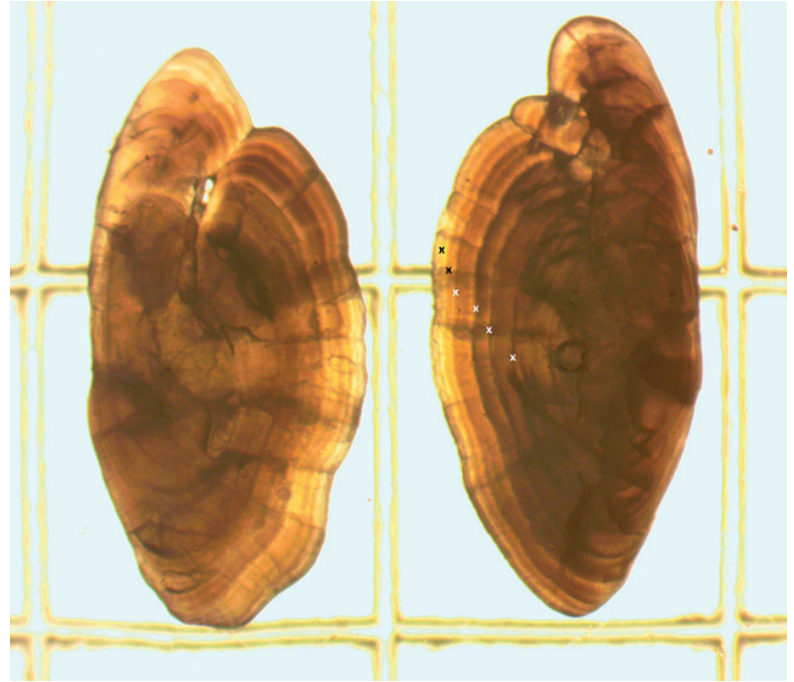

Figure 2. Otoliths (sagitta) of snakeblenny, L. lampraeteformis (aged 6+). $\mathrm{x}$ - annual rings.

also found in the stomach; these were juvenile acanthocephalan Echinorhynchus gadi Zoega in Müller, 1776 (Acanthocephala, Palaeacanthocephala, Echinorhynchidae). The gonads were in stage VII on Maier's scale (stage spent I); the ovaries were not fully empty, and a few opaque eggs remained. The gonad weight was $0.37 \mathrm{~g}$, and the gonadosomatic index GSI was $1.48 \%$.

Monitoring the most important commercial species (cod, herring, sprat, Sprattus sprattus (L.), salmon, Salmo salar L., and sea trout, Salmo trutta L.) is conducted by all Baltic countries according to guidelines and procedures agreed upon in forums such as the International Council for the Exploration of the Sea (ICES) and the European Union. These surveys collect many other species as bycatch (such as the L. lampretaeformis specimen presented in this work), which, potentially, can be used to monitor changes in overall fish communities and biodiversity (e.g., changes caused by fishing, species introductions, or climate change). In the current study, the specimen was caught at a depth of $40.9 \mathrm{~m}$, which corresponds with data presented by Makushok (1986) who reported the presence of this species at 30-200 m, but usually at 40-100 m. Similarly, Pieckel and Wawrzyniak (2016) noted one individual at $42.1 \mathrm{~m}$ in the Puck Bay. 
Both the metric and meristic characters of the specimen examined are within the ranges reported in Makushok (1986) for specimens from the northeastern Atlantic; however, no data on the morphometrics of L. lampretaeformis from the Baltic Sea are available. The female individual examined in this work, aged 6+, which was caught in April, had a low GSI that was typical of the post-spawning stage. According to Fricke et al. (1987), adults mature at the age of $3+$ and at a total length of $20 \mathrm{~cm}$, while the maximum length for the species is $50.0 \mathrm{~cm}$. Their spawning season is from December to January.

This species feeds on small crustaceans, mollusks, brittle stars, and worms (Makushok 1986). The stomachs of individuals found in bottom trawl catches in 1967-69 in Estonian waters were full of copepods (Ojaveer et al. 2003). In this study, Amphipoda and Priapulidae were noted in the stomach of the snakeblenny for the first time in a specimen from the Baltic Sea. Four juvenile acanthocephalan E. gadi were also found in the specimen's stomach. This parasite is the most common acanthocephalan in the southern Baltic, and it has been reported previously in specimens of this species only in Markowski (1933) from the Gulf of Gdańsk. From then until now the parasitological studies on snakeblenny have not been conducted on specimens from the Baltic Sea.

Little is known about the life cycle of $E$. gadi. This parasite has a wide spectrum of intermediate (Amphipoda) and final hosts (many fish species). Acanthocephalan larvae that are ingested with the food enter the alimentary tract of fish and most often mature in the intestine and/or pyloric caeca (Popiołek 2016). The acanthocephalans from the stomach of the L. lampretaeformis specimen in this study were juveniles, which probably means that they could have been ingested along with invertebrates (such as Pontoporeia femorata found in the stomach) that inhabit the Gulf of Gdańsk (Jęczmień and Szaniawska 2000) just before the individual was caught.

Fish that are definitive hosts become infected when they ingest amphipods containing mature cystacanth larvae. In the initial stage of life, L. lampretaeformis feeds on small crustaceans including Amphipoda, and the intermediate hosts of E. gadi are most likely amphipods. Additionally, the parasites mentioned could also have paratenic hosts, which include, among others, fish (Valtonen et al. 1983). The presence in the snakeblenny stomach the postlarval $E$. gadi suggest that this species is not a paratenic host.

L. lampretaeformis was designated as threatened in a 2007 assessment, and eutrophication and habitat loss are mentioned as the main threats to the species (HELCOM 2013). It is most likely negatively affected by the increase of areas with anoxic conditions in the Baltic Proper, consequently, its range of occurrence has decreased, and the quality of its habitat has deteriorated. L. lampretaeformis require cold, well oxygenated waters, therefore the potential impacts of climate change on the species must also be taken into consideration.

At present, since both its distribution area and population size are well above threshold levels, this species is currently considered as least concern (LC) and no protection actions are currently needed in the HELCOM area (HELCOM 2013), but more data should be collected on the status of this species. This statement is not reflected in the literature because of the lack of publications on L. lampretaeformis from the Baltic Sea region. According to Ojaveer et al. (2003), in recent decades no findings of snakeblenny from Estonian waters have been reported. Obviously, like in German waters (Fricke et al. 1996) the species is very rare now and is threatened with extinction. L. lampretaeformis is also very rare in the Kattegat and the North Sea where it is rarely caught in large numbers (Knijn et al. 1993). In Poland, L. lampretaeformis is partially protected by law (Regulation of the Minister of the Environment of 16 December 2016, on the protection of animal species; Journal of Laws, item 2183).

Author contributions. B.W. designed and performed the morphological study, analyzed the stomach contents, and wrote the paper; E.S. designed and performed the parasitological study; K.G. analyzed the data (age) and prepared part of the literature; M.S. analyzed the data and collected the specimen. 


\section{References}

Dudko S. 2008 - Monitoring of fish catches in the coastal zone of Pomeranian Bay - Project No OR 16-61 535-OR1 6000003/06. Publisher "Foka”, Szczecin 102 p. (in Polish).

Dudko S., Król S., Wojnar K., Wawrzyniak W. 2015 - Fisheries characteristics of ichthyofauna in the Pomeranian Bay - Project No 00004-61720-OR 1600005/10/11. Publisher: Szczecin Josephs's sons (in Polish).

Fricke R., Rechlin O., Winkler H., Bast H-D.O.G., Hahlbäck E. 1996 - Rote Liste und Artenliste der Rundmäuler und Meeresfische des Deutschen Meeres und Küstenbereichs der Ostsee - Schriftenreihe für Landschaftspflege und Naturschutz, 48: 83-90 (in Deutsch).

Grygiel W., Trella K. 2007 - Appearance of the 'visiting' fish species in the Polish research catches conducted in the southern Baltic (autumn-winter 1976-2004) - Copenhagen: International Council for the Exploration of the Sea, 1-19 pp. (ICES CM 2007/E:06).

Hayward P.J., Ryland J.S. 2011 - Handbook of the marine fauna of north-west Europe - Oxford, New York, Oxford University Press. Oxford, 800 p.

HELCOM 2013 - HELCOM Red List of Baltic Sea species in danger of becoming extinct - Balt. Sea Environ. Proc. No. 140.

Jęczmień W., Szaniawska A. 2000 - Changes in species composition of the genus Gammarus Fabr. in Puck Bay Oceanologia 42: 71-87.

Knijn R.J., Boon T.W., Heessen H.J.L., Hislop J.R.G. 1993 Atlas of North Sea fishes: based on bottom - trawl survey data for years 1985-1987. ICES Cooperative Research Report, 194. ICES: Copenhagen, 268 p.

Larson N. 2015 - Baltic International Acoustic Survey report, October 2014 - Aqua reports 2015: 12, Swedish University of Agricultural Sciences, Lysekil, 20 p.
Makushok V.E. 1986 - Lumpenidae - In: Fishes of the North-eastern Atlantic and the Mediterranean (Eds) P.J.P. Whitehead, M.-L. Bauchot, J.-C. Hureau, J. Nielsen, E. Tortonese, UNESCO, Paris: 1126-1129.

Markowski S. 1933 - Die Eingeweidewürmer der Fische des polnischen Balticums (Trematoda, Cestoda, Nematoda, Acanthocephala) - Arch. Hydrobiol. Ichthyol. 7: 1-58.

Muus B.J., Nielsen J.G. 1999 - Sea fish. Scandinavian Fishing Year Book - Hedehusene, Denmark, 340 p.

Ojaveer E., Pihu E., Saat T. 2003 - Fishes of Estonia - Estonian Academy Publishers, Tallin: 313-316.

Pieckiel P., Wawrzyniak W. 2016 - First record of rare fish snake blenny Lumpenus lampretaeformis (Walbaum 1792) in the Puck Bay - Bull. Mar. Inst. Gdańsk. 31: 7-10.

Popiołek M. 2016 - Parasites of Poland Acanthocephalans Acanthocephala. Polish Parasitological Society, Warszawa: 43-44 (in Polish).

Psuty-Lipska I., Garbacik-Wesołowska A. 1998 - Species composition and fish distribution in the Pomeranian Bay and the Szczecin Lagoon - Bull. Sea Fish. Inst. 3(145): 2-20.

Skóra K.E. 1996 - New and rare fish species from the Gulf of Gdańsk - Zool. Pol. 41, Suppl.: 113-130 (in Polish, English summary).

Williams K. 2007 - Evaluation of the macroscopic staging method for determining maturity of female walleye pollock Theragra chalcogramma in Shelikof Strait, Alaska - Alaska Fish. Res. Bull. 12: 252-263.

Valtonen E.T., Van Maren M.J., Timola O. 1983 - A note on the intermediate hosts of Echinorhynchus gadi Zoega, in Müller (Acanthocephala) in the Baltic Sea - Aquila Ser. Zool. 22: 93-97.

Żmudziński L. 1990 - Animal world of the Baltic Sea - Publisher WSiP, 195 p. (in Polish). 